\title{
An Analysis of Defence Expenditure and Economic Growth in South Africa
}

\author{
Teboho Jeremiah Mosikari \\ Economics Department, North West University (NWU), Mafikeng campus, South Africa, \\ Email : tebza.minus@yahoo.com
}

Keabetswe Matlwa

Department of National Treasury, Chief Directorate: Justice and Protection Services (JPS),

Email : keabetswe.matlwa@treasury.gov.za

\section{Doi:10.5901/mjss.2014.v5n20p2769}

\section{Abstract}

This research paper investigates the relationship between defence expenditure and economic growth in South Africa. It is understood that South African Defence Force plays a vital role in peace keeping security in African and SADC as a region. This makes it a particularly interesting case study on nexus between defence expenditure and economic growth. This investigation presents such a study, by estimating an econometric model of the South African military expenditure in considering pure economic factors. The period of the study covers from 1988 to 2012. On the basis of determining the long term equilibrium the application of Johansen cointegration and Engel-Granger were applied. At the later stage the technique of Granger causality was performed on variables of interest in the study. The study concludes that there is long run relationship between defence expenditure and economic growth. Also for causal analysis military expenditure seem to granger cause gross domestic product per capita at 5 percent significance level.

\section{Introduction}

Since the beginning of life the protection of every human kind has been a priority of the government. It is realised through the literature that citizens protection became one of the political mandate. Defence spending it can be described by a situation where the country ensures its internal and external security for its citizens. From the economics point of view it means that defence spending compete with all other public goods the inhabitants may need. According to Shahbaz, Afza and Shabbir (2013) there are two paths in which military expenditure may affect economic growth. Firstly, they explains that a rise in military expenditure may increases total demand by stimulating output and ultimately economic growth. Secondly, an increase in defence expenditure may also lead to improvements in infrastructure. World military expenditure in 2004 peaked at U\$ 1 trillion, where United States accounts for 47 percent in the world defence expenditure, (World Council of Churches, 2005). Prior to portray the picture of military expenditure in South Africa, this study takes a closer look at military expenditure from continental view. According to Smaldone (n.d) African military expenditure has been a small fraction in comparison of global outlays for military. It is claimed that during 1989 African countries constituted 1.5 percent of world military outlay, compared to decade before of 1.8 percent, (Smaldone, n.d). Perlo-freeman, Sköns, Solmirano and Wilandh (2013) indicates that in Sub-Sahara military expenditure increased strongly for previous years, but for first time since 2003 it fell by 3.2 percent.

Since South Africa is the most advanced economy on the African continent. Stalenheim, Fruchart, Omitoogun and Perdomo (2006) pointed that military expenditure in Africa rose by less than 1 per cent in 2005, in which, South Africa was among countries accounted for 62 per cent of Africa's military spending. During the apartheid government, South Africa built up one of the higher arms industries of any newly industrialising economy. Batchelor, Dunne and Lamb (2002) stated that during the 1970s and 1980s there were sustained upward trends in military spending as a result of South Africa's military involvement in Namibia/Angola. However, South Africa's military expenditure has been reduced substantially in the late 1980s. This was attributed by fact that South Africa had ended its apartheid regime and the end of the Cold War. After nearly 10 years of defence budget cuts, by the end of the 1990s South Africa's military spending as a percentage of GDP was at the same level as it had been in the early 1960s.

This study intends to briefly review the literature on military spending in South Africa and other international studies. It then investigates the causal linkages link between gross domestic product (GDP) and military spending. More 
importantly, the purpose of this study is to examine some of the important questions. Firstly, is there long run equilibrium between defence expenditure and economic growth? Secondly, is there causality existing between defence expenditure and economic growth in South Africa or visa versa? It should be pointed that former Ministry of Defence in 2010 in the budget speech described military budget of South Africa as "shoestring" and insufficient for one of Africa "s biggest contributors to peacekeeping forces, by mentioning that at least the budget for defence should be 2 percent of the GDP. This statement has drawn some attention to this study to explore econometric relation between defence expenditure and economic growth.

The study is organized as follows: Section 2 discusses the literature survey at international level and South African survey later on. Section 3 presents data and methodology for the model specifications. Section 3 discusses the variables descriptions used in this study. Section 4 and 5 is econometric methods and model specification respectively. Section 6 and 7 is motivation for variables used and empirical results. Lastly, section 8 its summary and conclusion.

\section{Literature Survey}

Military has been a major item of national expenditure in many countries, but it has received little attention from researchers. This has led Tambudzai (n.d. ${ }^{1}$ ) enlightens the rationality of the defence budgetary process in Southern Africa through identifying the main factors that influence military expenditure. The researcher used panel data analysis to study the behaviour of a particular group of countries over a given time period. For estimation, the study used time series data from 1996 to 2005 for each of the 12 countries in which it includes most of the countries in Southern Africa. The result of the study validates the significance of both economic and strategic variables in the determination of military expenditure in developing countries. It was found that the change in military burden is not explained by previous growth rates of military expenditure. The study also indicated the importance of GDP per capita and wars as determinants of military expenditure in Southern Africa.

Dunne and Perlo-Freeman (2001) undertakes a study in an attempt to evaluate the driving forces behind military spending in developing countries by comparing a period during the Cold War with the period afterwards. Their study is concerned with developing economies and is particularly concerned with the impact of changes in security webs on military spending. The authors carried out separate time frames in which, one for (1981-88) during the Cold War the other for (1990-97) Post Cold-War. Results from Cold War time the coefficient of income term is insignificant, suggesting that military spending rises more or less in proportion to income.

Military spending in Egypt has seen marked changes that have passed through different phases. Aamer, AbuQarn, Dunne, Abdelfattah and Zaher (2010) undertake a study on time series analysis of the evolution of military spending in Egypt over the period 1960-2007. The results from the regression analysis suggest that military burden in Egypt is mainly determined by an auto regressive (AR) process, with some important economic and strategic factors. The findings indicate that an increase in GDP decreases the military burden of Egypt. Several studies such as Khalid and Mustapha (2014), Rashid and Arif (2012) have been conducted on the determinants of military expenditure in developing countries. Tambudzai (2006) tested the effects of economic factors, external factors, and geopolitical factors on Zimbabwe's military expenditure. The study was encouraged by the fact that the current economic crisis makes Zimbabwe's defence expenditures of concern. The study employs ordinary least squares (OLS) and uses time series from 1980 to 2003. The finding in the long run indicates that military expenditure and income shows a negative sign at 5 per cent significance level. The effect of military expenditures on economic growth in Pakistan and its causality analysis were investigated by Shahbaz, Afza and Shabbir (2013). The findings of their study have confirmed the long run equilibrium between military expenditure and economic growth. Precisely, the study showed a negative impact of military expenditure and economic growth for Pakistan. Anwar, Rafique and Joiya (2012) examined the defense spending and its linkages with economic growth in Pakistan. The study applied Johansen cointegration method and causality analysis. It was concluded by the study that military expenditure and economic growth are cointegrated, and causality runs from economic growth to defence spending. As is the trend in the literature that military expenditure is causally prior to economic growth, Dunne, Nikolaidou and Vougas (1998) empirically investigated the hypothesis in Greece and Turkey. Their study indicates that for Greece there is a positive impact of military expenditure on economic growth. Conversely, for Turkey the study finds a significant negative causal link from military expenditure to economic growth.

In terms of the literature of studies in South Africa Dunne and Vougas (1999) found evidence of a significant negative effect of military burden on the economic growth over the period from 1964 to 1996 . The study applied Granger causality within VAR system which suggests no significant relationship among the variables. The authors further

\footnotetext{
${ }^{1}$ n.d means no date for that source
} 
suggested that the military expenditure of the apartheid system did have a bad effect on the growth of South Africa. Another study conducted in South Africa was that of Aye, Balcilar, Dunne, Gupta and van Eyden (2013) found that at 5 percent significant level no cointegration between GDP and military expenditure. Their study only applied the techniques of Johansen cointegration. The current study intents to contribute in the literature in following ways: firstly, this study extends on the period of investigation compared to previous studies such as Dunne and Vougas (1999). Secondly, this study contributes in the literature by applying two types of cointegration to rely on the robust results of cointegration taking into consideration the use of two techniques. Lastly, this study contributes to the existing literature by using only economic variables in explaining military expenditure unlike previous studies. This study argues that military expenditure its economic issue therefore it should be explained by economic variables.

\section{Data Description}

To analyse the impact of economic growth on defence expenditure, the current study uses data spanning for 1988 to 2012. The data was extracted International Monetary Fund (IMF) and Stolkhom International Peace Research Institute (SIPRI) websites. All the variables used in the study were transformed into logarithms. The variables are as follows: government expenditure on military spending, government spending on education, government spending on health, population growth and gross domestic product per capita.

\section{Econometric Methods}

This research paper applies the Morden econometric methods such as unit root testing, cointegration and causality test to investigate the phenomena in hand. In the first step the current study will apply Augmented Dickey-Fuller ${ }^{2}$ test unit root test to investigate the order of integration in the variables under scrutiny. After determining the order of integration on the variables the next step is to determine whether they cointegrated or not with the application of Johansen cointegration and Engel-Granger cointegration test. Lastly, after determining that there is a long run relationship among the variables this study will do the causality test.

\section{Model Description}

This paper will adopt the modified model by Tambudzai (2006), who estimated determinates of military expenditure in Zimbabwe. The current econometric model will be as follows:

Milex $_{t}=f\left(\right.$ PoP $_{t}, E D U C_{t}, G D P C_{t}, H E A T_{t}$,

Where for the purpose of estimation, question (1.1) it can be expressed in logarithm form as follows:

lnMilex $_{t}=\beta_{0}+\ln P o P_{t}+\ln E D U C_{t}+\ln G D P C_{t}+\ln H E A T_{t}+\mu_{t}$

Where $\operatorname{lnMilex}_{t}$ is the defence/military spending by government, $\operatorname{lnPo} P_{t}$ is the population growth, $E D U C_{t}$ is the general government expenditure on education, $G D P C_{t}$ is the South African gross domestic product per capita, $H E A T_{t}$ is general government expenditure on health and lastly, $\mu_{t}$ represent the disturbance term for all other factors not included in the model but not considered.

\section{Motivation for Some Variables Used}

Gross domestic product per capita is defined as the total market value of all final goods and services produced annually within the boundaries of a country, using both domestic and foreign-supplied resources divided by population. Collier and Hoeffler (2002) indicated that resource availability which means what a country can afford is viewed as the most important determinant of the level of military expenditure. Most of the studies have used the growth rate of GDP and as GDP rises, a country has more resources for production and greater means and need for protection. According to Nikolaidou (n.d) the inclusion of non-military government expenditure that is government expenditure on education and health in the model represents the economic burden of defence and is expected to enter the equation with a negative sign to account for the opportunity cost of defence. Lastly, population variable is incorporated to confine possible size effects. Dunne and Perlo-Freeman (2001) stated that it may be seen as giving some intrinsic security, reducing the need for military expenditure, or may reduce costs by allowing reliance on a large army rather than hi-tech equipment. On the other hand "public good" theory would suggest that a high population makes military spending more effective, as it

\footnotetext{
${ }_{2}^{2}$ Augmented Dickey-Fuller well known as ADF test.
} 
benefits a larger number of people as a "pure public good".

\section{Empirical Results}

Pre-getting to any econometric analysis for this paper, Table.1 below shows descriptive statistics for the study, for the economy of South Africa GDP per capita is U\$31345.34 million, where on average South Africa spend U\$71329.28 million also U\$38048.20 million on health. The South African average population is 43 million.

Table 1: Descriptive statistics of the variables

\begin{tabular}{|l|c|c|c|c|c|}
\hline & GDPC & EDUC & HEAT & MILEX & POP \\
\hline Mean & 31345.34 & 71329.28 & 38048.20 & 4616.800 & 43.87480 \\
Median & 30183.09 & 53451.00 & 25662.00 & 4475.000 & 44.52300 \\
Maximum & 37471.20 & 186145.0 & 109405.0 & 7741.000 & 51.19700 \\
Minimum & 27090.67 & 10886.00 & 5849.000 & 2892.000 & 35.28000 \\
Std. Dev. & 3670.380 & 53613.00 & 32229.10 & 1225.515 & 4.789925 \\
Skewness & 0.593101 & 0.928782 & 1.110045 & 1.297281 & -0.236773 \\
Kurtosis & 1.791652 & 2.790665 & 3.048717 & 4.358582 & 1.920803 \\
\hline Jarque-Bera & 2.986647 & 3.639965 & 5.136639 & 8.934890 & 1.446782 \\
Probability & 0.224625 & 0.162029 & 0.076664 & 0.011477 & 0.485104 \\
\hline Sum & 783633.4 & 1783232. & 951205.0 & 115420.0 & 1096.870 \\
Sum Sq. Dev. & $3.23 E+08$ & $6.90 \mathrm{E}+10$ & $2.49 \mathrm{E}+10$ & 36045280 & 550.6411 \\
Observations & 25 & 25 & 25 & 25 & 25 \\
\hline
\end{tabular}

The table 2 below it shows the results for ADF unit root test, this test is important before the cointegration part. The table shows that in the first column represents the variables used, the second and third column gives the ADF model used. The fourth column is the ADF statistics and lastly, is the critical values column. It shows that following the results of ADF all the variables under study are non-stationary at levels, but this hypothesis changes after the variables are first differenced.

Table 2: ADF unit root results

\begin{tabular}{|c|c|c|c|c|c|}
\hline \multirow{2}{*}{ Variables } & & \multirow{2}{*}{ ADF Model } & \multirow{2}{*}{ ADF Statistics } & \multicolumn{2}{|c|}{ Critical values } \\
\hline & & & & $5 \%$ & $10 \%$ \\
\hline \multirow{2}{*}{ MILEX } & Levels & $\begin{array}{c}\text { Trend + Constant } \\
\text { Constant }\end{array}$ & $\begin{array}{l}-2.650565 \\
-3.111255\end{array}$ & $\begin{array}{l}-3.622033 \\
-2.998064\end{array}$ & $\begin{array}{l}-3.248592 \\
-2.638752\end{array}$ \\
\hline & First levels & $\begin{array}{l}\text { Trend + Constant } \\
\text { Constant }\end{array}$ & $\begin{array}{l}-4.961446^{\star \star} \\
-5.104064^{\star *}\end{array}$ & $\begin{array}{l}-3.632896 \\
-3.004861\end{array}$ & $\begin{array}{l}-3.254671 \\
-2.642242\end{array}$ \\
\hline \multirow{2}{*}{ POP } & Levels & $\begin{array}{c}\text { Trend + Constant } \\
\text { Constant }\end{array}$ & $\begin{array}{l}-2.355833 \\
-2.485146\end{array}$ & $\begin{array}{l}-3.612199 \\
-2.998064\end{array}$ & $\begin{array}{l}-3.243079 \\
-2.638752\end{array}$ \\
\hline & First levels & $\begin{array}{c}\text { Trend + Constant } \\
\text { Constant }\end{array}$ & $\begin{array}{l}-6.246713^{\star *} \\
-6.343124^{\star \star}\end{array}$ & $\begin{array}{l}-3.632896 \\
-3.004861\end{array}$ & $\begin{array}{l}-3.254671 \\
-2.642242\end{array}$ \\
\hline \multirow{2}{*}{ EDUC } & Levels & $\begin{array}{c}\text { Trend + Constant } \\
\text { Constant }\end{array}$ & $\begin{array}{l}-2.399231 \\
-2.481555\end{array}$ & $\begin{array}{l}-3.612199 \\
-2.991878\end{array}$ & $\begin{array}{l}-3.243079 \\
-2.635542\end{array}$ \\
\hline & First levels & $\begin{array}{c}\text { Trend + Constant } \\
\text { Constant }\end{array}$ & $\begin{array}{l}-6.435497^{\star \star} \\
-6.595295^{\star \star}\end{array}$ & $\begin{array}{l}-3.632896 \\
-3.004861\end{array}$ & $\begin{array}{l}-3.254671 \\
-2.642242\end{array}$ \\
\hline \multirow{2}{*}{ HEAT } & Levels & $\begin{array}{c}\text { Trend + Constant } \\
\text { Constant }\end{array}$ & $\begin{array}{l}-2.845095 \\
-0.887948\end{array}$ & $\begin{array}{l}-3.622033 \\
-2.991878\end{array}$ & $\begin{array}{l}-3.248592 \\
-2.635542\end{array}$ \\
\hline & First levels & $\begin{array}{c}\text { Trend + Constant } \\
\text { Constant }\end{array}$ & $\begin{array}{l}-4.506590^{\star \star} \\
-4.652459^{\star \star}\end{array}$ & $\begin{array}{l}-3.644963 \\
-3.012363\end{array}$ & $\begin{array}{l}-3.261452 \\
-2.646119\end{array}$ \\
\hline \multirow{2}{*}{ GDPC } & Levels & $\begin{array}{c}\text { Trend + Constant } \\
\text { Constant }\end{array}$ & $\begin{array}{l}-3.504017 \\
-0.518551\end{array}$ & $\begin{array}{l}-3.622033 \\
-2.998064\end{array}$ & $\begin{array}{l}-3.248592 \\
-2.638752\end{array}$ \\
\hline & First levels & $\begin{array}{c}\text { Trend + Constant } \\
\text { Constant }\end{array}$ & $\begin{array}{l}-3.571058^{*} \\
-5.336118^{\star *}\end{array}$ & $\begin{array}{l}-3.690814 \\
-3.004861\end{array}$ & $\begin{array}{l}-3.286909 \\
-2.642242\end{array}$ \\
\hline
\end{tabular}

* $10 \%$ significance level, ** $5 \%$ significance level, ${ }^{* \star} 1 \%$ significance level

This study also employs the technique of correlation relations, this application it is important because it describes the degree of relationship between variables in the matrices. Table 3 shows the correlation among the variables. the results 
shows that all the variables population, government expenditure on health and education are negatively correlated with defence expenditure but their coefficients are not that higher except for population. Only the correlation between GDP per capita and defence expenditure is positive with a low coefficient.

Table 3: Matrices correlation results.

\begin{tabular}{|c|c|c|c|c|c|}
\hline & LOG_MILEX & LOG_GDPC & LOG_HEAT & LOG_EDUC & LOG_POP \\
\hline LOG_MILEX & 1.000000 & 0.113240 & -0.419149 & -0.477118 & -0.504472 \\
LOG_GDPC & 0.113240 & 1.000000 & 0.826966 & 0.785710 & 0.772004 \\
LOG_HEAT & -0.419149 & 0.826966 & 1.000000 & 0.996605 & 0.989588 \\
LOG_EDUC & -0.477118 & 0.785710 & 0.996605 & 1.000000 & 0.995101 \\
LOG_POP & -0.504472 & 0.772004 & 0.989588 & 0.995101 & 1.000000 \\
\hline
\end{tabular}

The following step after confirming the stationarity of variables is the cointegration of variables. The method of Johansen cointegration is applied in this study. This method was introduced by Johansen (1991), after the criticism of the former technique of Engle-Granger two step model. But before that the study needs to determine the lag length to be used in cointegration based on AIC and SIC. The results show that the optimal lag length is 3.

Table 4: Lag length selection.

\begin{tabular}{|c|c|c|c|c|c|c|}
\hline Lag & LogL & LR & FPE & AIC & SC & HQ \\
\hline 0 & 147.0676 & NA & $9.16 e-13$ & -13.53024 & -13.28155 & -13.47627 \\
1 & 280.8923 & 191.1782 & $3.13 e-17$ & -23.89450 & -22.40233 & -23.57066 \\
2 & 306.5582 & 24.44376 & $4.83 e-17$ & -23.95793 & -21.22227 & -23.36422 \\
3 & 417.4274 & $52.79486^{*}$ & $8.29 e-20^{\star}$ & -32.13595 & -28.15681 & -31.27237 \\
4 & 2177.164 & 0.000000 & NA & $-197.3489^{\star}$ & $-192.1263^{\star}$ & $-196.2155^{\star}$ \\
\hline
\end{tabular}

* indicates lag order selected by the criterion

$\mathrm{LR}^{3}, \mathrm{FPE}^{4}, \mathrm{AlC}^{5}, \mathrm{SC}^{6}, \mathrm{HQ}^{7}$

Table 5 and 6 below shows the results for Johansen cointegration test, in both tables the first column represent the number of cointegrating equations, the second column represent the trace statistics for table 5 but max-eigen statistic for table 6 . The last column represent the critical values of Johansen cointegration test at $5 \%$ significance level.

Table 5: Unrestricted Cointegration Rank Test (Trace)

\begin{tabular}{|c|c|c|}
\hline Hypothesized No. of CE(s) & Trace Statistic & 0.05 Critical Value \\
\hline None * $^{*}$ & 243.6123 & 69.81889 \\
At most 1 & 127.2291 & 47.85613 \\
At most 2 * & 48.90062 & 29.79707 \\
At most 3 * & 18.71050 & 15.49471 \\
At most 4 & 0.055557 & 3.841466 \\
\hline
\end{tabular}

Trace test indicates 4 cointegrating eqn(s) at the 0.05 level, * denotes rejection of the hypothesis at the 0.05 level, **MacKinnon-Haug-Michelis (1999) p-values

\footnotetext{
${ }^{3}$ sequential modified LR test statistic (each test at $5 \%$ level)

${ }^{4}$ Final prediction error

${ }^{5}$ Akaike information criterion

${ }^{6}$ Schwarz information criterion

7Hannan-Quinn information criterion
} 
Table 6: Unrestricted Cointegration Rank Test (Maximum Eigenvalue)

\begin{tabular}{|c|c|c|}
\hline Hypothesized No. of CE(s) & Max-Eigen Statistic & $\mathbf{0 . 0 5}$ Critical Value \\
\hline None * $^{*}$ & 116.3832 & 33.87687 \\
At most 1 $^{*}$ & 78.32843 & 27.58434 \\
At most 2 & 30.19013 & 21.13162 \\
At most 3 & 18.65494 & 14.26460 \\
At most 4 & 0.055557 & 3.841466 \\
\hline
\end{tabular}

Max-eigenvalue test indicates 4 cointegrating eqn(s) at the 0.05 level, ${ }^{*}$ denotes rejection of the hypothesis at the 0.05 level, **MacKinnon-Haug-Michelis (1999) p-values

The results from trace test and maximum eigenvalue test indicates that there are four cointegrating vectors between the variables at 0.05 percent significance level. Cointegrating vectors are between military expenditure, gross domestic product per capita, population, government expenditure on health and education. The test it simply concludes by comparing the trace statistic of 24.612 and its corresponding critical value. If the critical value is less than the trace test then there is an existence of long run equilibrium, the same applies to test of maximum eigenvalue. These results of cointegration are also confirmed by applying Engel-Granger cointegration below:

Table 7: Engel- Granger cointegration test results

\begin{tabular}{|c|c|c|}
\hline \multirow{2}{*}{ Significance level } & \multicolumn{2}{|c|}{ Critical value } \\
\cline { 2 - 3 } & Intercept & Trend \& intercept \\
\hline $1 \%$ & -4.96 & -5.25 \\
$5 \%$ & -4.42 & -4.72 \\
$10 \%$ & -4.13 & $-4.43^{\star}$ \\
\hline
\end{tabular}

Note: Computed ADF test-statistics (intercept) : -3.853, ADF test-statistics (intercept \& trend): -4.564, Critical values are cited from Davison and Mackinnon (1993).

Table 7 above presents the results for Engel-Granger cointegration test. The study finds that the computed ADF teststatistics for this study is -4.564 which is less than the critical value of -4.43 at $10 \%$ level. This implies that the null hypothesis of no cointegration in the long-run relationship is rejected. These findings reveal long run equilibrium between Milex, GDPC, HEAT, EDUC and POP.

\section{Granger Causality Results}

Since the study has confirmed the existence of cointegration for variables under study, the final step is to determine the direction of causality. The application of pairwise Granger causality was used to examine the causal relationship between military expenditure and economic growth since this is variables of interest. The results for causality are presented in table 8.

Table 8: Granger causality results

\begin{tabular}{|c|c|c|c|}
\hline Null Hypothesis: & Obs & F-Statistic & Prob. \\
\hline GDPC does not cause MILEX & \multirow{2}{*}{22} & 0.51765 & 0.6765 \\
MILEX does not cause GDPC & & 3.49982 & $0.0419^{\star}$ \\
\hline
\end{tabular}

*Indicates the rejection of the null hypothesis

The rejection rule is that, when the probability value ( $p$-value) is less than the level of significance at 5 percent. In this case it can be observed that the first hypothesis it can not be rejected. Conversely, the second hypothesis it is rejected in favour that military expenditure does granger causes gross domestic product per capita.

\section{Summary and Conclusion}

The present investigation studied the relationship between defence expenditure and economic growth in South Africa. The investigation used annual time series data spanning from 1988 to 2012. The empirical analysis suggested that all the 
variables used in this study were subject to unit root testing. On the basis of determining the long term equilibrium the application of Johansen cointegration and Engel-Granger were applied. At the later stage the technique of Granger causality was performed on variables of interest in the study.

In conclusion, the following research questions were considered: is there long run equilibrium between defence expenditure and economic growth? From this question the study can conclude that there is long run relationship between defence expenditure and economic growth. Hence, any policy suggestion to either of the variable may affect the other. These findings are consistent with the study of Shahbaz, Afza and Shabbir (2013). The secondly, research question was: is there causality existing between defence expenditure and economic growth in South Africa or visa versa? From this question it is concluded that there is no causality running from gross domestic product per capita to military expenditure. This implies that gross domestic product per capita does not seem to be a pave way to cause either higher or less military expenditure. Conversely, looking on the other hypothesis this is interesting that military expenditure seem to granger cause gross domestic product per capita at 5 percent significance level. Also these findings are similar to Dunne, Nikolaidou and Vougas (1998) specifically for Turkey case study. Based on causality outcomes of the study it is recommended to policy makers that the decision for military expenditure should not be based on gross domestic product as a stick-yard.

\section{References}

Aamer S. Abu-Qarn \& J Paul Dunne \& Yasmine M. Abdelfattah \& Shadwa Zaher (2010) The demand for military spending in Egypt. Defence and Peace Economics . Working Papers 1001, Department of Accounting, Economics and Finance, Bristol Business School, University of the West of England, Bristol.

Anwar M.A, Rafique Z. And Joiya S.A (2012) "Defense spending-economic growth nexus: a case study of Pakistan", Pakistan Economic and Social Review, Volume 50, No. 2 (Winter 2012), pp. 163-182

Aye G.C, Balcilar M, Dunne J.P, Gupta R. and van Eyden R., (2013) Military Expenditure, Economic Growth and Structural Instability: A Case Study of South Africa, University of Pretoria, Department of Economics Working Paper Series

Batchelor P., Dunne P. and Lamb G. (2002) "The Demand for Military Spending in South Africa". Journal of Peace Research, vol. 39, no. 3, 2002, pp. 315-330 Sage Publications (London, Thousand Oaks, CA and New Delhi)

Collier, P. and A. Hoeffler. (2002) "On the Incidence of Civil War in Africa", Journal of Conflict Resolution 46, 13-28.

Davidson, R. and MacKinnon, J. G. (1993) "Estimation and inference in Econometrics", Oxford University Press, New York.

Dickey, D. and W. Fuller (1979). Distribution of the Estimators for Autoregressive Time Series with a Unit Root, Journal of the American Statistical Association, 74, 427-431.

Dunne P. and Perlo-Freeman S. (2001) "The Demand for Military Spending in Developing Countries". Centre for Applied Research in Economics Middlesex University Business School August 2001. Paper presented to the Second CesA/IDN International Conference on Defence Economics and Security in Mediterranean and Sub-Saharan Africa. Lisbon, June 2000.

Dunne P. and Vougas D. (1999) "Military Spending and Economic Growth in South Africa: A Causal Analysis", The Journal of Conflict Resolution, Vol. 43, No. 4 (Aug., 1999), pp. 521-537

Dunne P., Nikolaidou E. and Vougas D. (1998) "Defence Spending and Economic Growth: A Causal Analysis for Greece and Turkey", Paper presented at the ERC/METU International Conference on Economics, 9th - 12 ${ }^{\text {th }}$ September, 1998, Ankara, Turkey.

Engle, R.F., and Granger, C.W.J. (1987) "Co-integration and Error Correction: Representation, Estimation and Testing", Econometrica, Vol.55, 251-276.

Johansen, S. (1991) "Estimation and Hypothesis Testing of Cointegration Vectors in Gaussian Vector Autoregressive Models". Econometrica, 59, 1551-1580.

Khalid M.A and Mustapha A.B, (2014) "Long-run relationships and causality tests between military expenditure and economic growth in India", The Economics and Finance Letters, 2014, 1(6): 49-58

Nikolaidou e. (n.d) "The demand for military expenditure: evidence from the EU15 (1961-2005)" Proceedings of the 10th Annual International Conference on Economics and Security.URL:http://www.city.academic.gr/special/events/economics_and_security 09/2006/17-Nikolaidou.pdf

Perlo-freeman S., Sköns E., Solmirano C. and Wilandh H., (2013) "Trends in world military expenditure, 2012" SIPRI Fact Sheet, April 2013. URL link:http://books.sipri.org/files/FS/SIPRIFS1304.pdf

Rashid A.K.M and Arif Z.U (2012) "Does military expenditure influence economic growth in developing Countries? A cointegration analysis", International Refereed Research Journal Vol.- III, Issue 3(1), July 2012 [93]

Shahbaz M., Afza T. and Shabbir M.S (2013) "Does Defence spending impede economic growth? Cointegration and causality analysis for Pakistan", Defence and Peace Economics, 24:2, 105-120

Smaldone J.P (n.d) "African military spending: Defence versus development?" African Security Review 15.4, Institute for Security Studies, The Liberal Studies Program, Georgetown University, Washington, DC.

Stalenheim P, Fruchart D, Omitoogun W, and Perdomo C., (2006) 'Military expenditure', Stolkhom International Peace Research Institute, [SIPRI] Yearbook 2006 (Oxford University Press: Oxford, 2006), pp. 295-324.

Tambudzai Z. (2006) "Determinants of Zimbabwe's Military Expenditure", 1980- 2003. Journal of Development Perspectives, 2 (1):103- 
120.

Tambudzai Z. (n.d) "Military Burden Determinants in Southern Africa, 1996-2005: A Cross-section and Panel Data Analysis". Paper is to be presented at Economic Development in Africa Conference. Venue: St Catherine.s College. Ref No 76.

World Council of Churches (2005) "World Military Expenditures, A compilation of data and facts related to military spending, education and health. Geneva, Switzerland, 2005. URLlink:http://www.overcomingviolence.org/fileadmin/dov/files/wcc_resources/dov_ documents/MilitarySpendingReport.pdf 